\title{
The Spain That Enslaves and Expels: Moriscos and Muslim Captives (1492 to 1767-1791)
}

In Spain, as in Europe as a whole, Muslims were present in larger numbers from the sixteenth through the eighteenth centuries than has formerly been realized. As we noted above, the greatest attention has been focused on two specific minority groups, Moriscos and slaves. The first were expelled from Spain between 1609 and 1614 , although a certain number managed to evade expulsion or return to the Peninsula later on. The second were almost always a minority among all slaves in Spain in the Early Modern period, except at specific times and places; the vast majority came from the Atlantic coast of sub-Saharan Africa, although many of those arrived already Islamized. It is also true that the number of slaves on Spanish territory fell drastically from the second half of the seventeenth century and continued its decline through the eighteenth, though there was a slight increase in the late 1700 s as Spain joined the slave trade with the American colonies.

Most historical works about Muslims in Spain, therefore, concentrate on the Moriscos (more or less Christianized, more or less Islamized) from 1492 to 1614. And the enormous bibliography on slavery concentrates on slaves from subSaharan Africa in the sixteenth and seventeenth centuries, leaving Muslims on the margins. Moriscos and slaves, in short, have captured almost all the interest of historians even though, as we shall see, free Muslims were very numerous.

For more than a century historians, both in Spain and elsewhere, have focused on the Morisco minority and produced oceans of research which it is impossible to summarize here. It concerns virtually every topic related to Muslims who remained in the lands reconquered by the Christians: the Mudejars of Castile, the Moors of Aragon, the Sarraïns of Valencia. All (estimated at between three hundred thousand and six hundred thousand souls) were subsumed under the term "Moriscos," which arose after the Christian conquest of Granada in 1492. The capitulations offered to the vanquished promised that all Muslims who chose to remain in the Peninsula could do so freely and continue to exercise their religion. This status continued the medieval practice, not 
unlike the tolerance shown toward dhimmis or "People of the Book," Christians and Jews, in Islamic lands. Yet pressure to convert began to be applied almost immediately, and when certain leading Nasrid families accepted baptism, tensions arose that led to the Albaicín revolt in Granada in 1499; after spreading to the Alpujarras mountains it was crushed in 1501 . One immediate result was the 1502 decree of forcible conversion imposed on all Muslims in Castile and Granada, who would be called "Moriscos" from then on. In 1515-1516 conversion was imposed on the Mudejars of Navarre and in 1526 on the Muslims of the Crown of Aragon. The Moriscos, already stripped of their land and property and forced to adopt Christianity, remained under suspicion by the authorities, especially the Catholic Church, which was loath to allow any religious manifestation other than its own. This position hardened after the Council of Trent $\left(1545^{-1563)}\right.$ and the consolidation of the Counter-Reformation. ${ }^{1}$ The Moriscos' restiveness brought about a new uprising, the War of Granada or the Alpujarras (1568-1571), again savagely repressed by the king's armies. Most of the conquered survivors were exiled to other areas across the Peninsula, while many prisoners, including women and children, were enslaved ${ }^{2}$ - some actually coming to be owned by other Moriscos. ${ }^{3}$ Hostility against them never ceased, as they were thought to form an Ottoman fifth column within Spain. ${ }^{4}$

The volume of existing bibliography on the Moriscos makes it unnecessary to discuss them at length here. Important research on the group was produced throughout the nineteenth century ${ }^{5}$ and the topic received renewed attention in the 195 os $^{6}$ and 1970s. ${ }^{7}$ Dozens more books have appeared since then, in addition to innumerable journal articles, book chapters, and conference papers that, with few exceptions, I cannot take account of here. ${ }^{8}$

1 Poutrin, Convertir les musulmans.

2 Garrido García, "La esclavitud morisca" and "La esclavitud en el reino de Granada"; Vincent, "Les esclaves d'Almeria"; Andújar Castillo, "Del esclavo morisco al berberisco"; Cabrillana, "Esclavos moriscos en la Almería."

3 Martín Casares, La esclavitud, 275-93, "Moriscos propietarios de esclavos," and "Moriscos propietarios de personas esclavizadas."

Rubiera Mata, Carlos v, los moriscos y el Islam; Hess, "The Moriscos: An Ottoman Fifth Column."

Boronat y Barrachina, Los moriscos españoles; Lea, The Moriscos of Spain/Los moriscos españoles; Danvila y Collado, La expulsión de los moriscos; Janer, Condición social de los moriscos; Circout, Histoire des Mores, Mudejars, et des Morisques.

6 Lapeyre, Géographie de l'Espagne morisque; Caro Baroja, Los moriscos del Reino de Granada.

7 Domínguez Ortiz and Vincent, Historia de los moriscos; Cardaillac, Morisques et chrétiens.

8 Amelang, Historias paralelas; Márquez Villanueva, Moros, moriscos y turcos; Vincent, El río morisco; Carrasco, La Monarchie Catholique et les Morisques; Candau Chacón, Los moriscos en el espejo del tiempo; Perceval, Todos son uno; Galmés de Fuentes, Los moriscos (desde su misma orilla); Epalza, Los moriscos antes y después de su expulsión; Temimi, 
Because most Moriscos lived in three regions of Spain, the existing bibliography is especially rich for those former kingdoms: Aragon, ${ }^{9}$ Valencia, ${ }^{10}$ and the former Nasrid kingdom of Granada, ${ }^{11}$ which included the region of Almería. ${ }^{2}$ But there is much research on the lives and fortunes of Moriscos in all the territories of the monarchy. In western Andalusia the main centers were Seville ${ }^{13}$ and Córdoba. ${ }^{14}$ In Murcia, most though not all studies have concerned the Moriscos of the Valle de Ricote. ${ }^{15}$ In La Mancha, we are well informed about the Campo de Calatrava and Almansa. ${ }^{16}$ The former kingdoms of Castile and León have yielded studies centered on Toledo, ${ }^{17}$ Ciudad Real, ${ }^{18}$ Cuenca, ${ }^{19}$ Valladolid, ${ }^{20}$ Salamanca, ${ }^{21}$ Ávila, ${ }^{22}$ and Zamora. ${ }^{23}$ The case of Catalonia is also well known. ${ }^{24}$

Métiers, vie religieuse et problematique, Las prácticas musulmanas, and Religion, identité; Bunes Ibarra, Los moriscos en el pensamiento histórico.

9 Conte, Los moriscos de la ciudad de Huesca; Carrasco Urgoiti, El problema morisco en Aragón.

10 Catalá Sanz and Urzainqui Sánchez, La conjura morisca de 1570; Mas i Forners et al., La senda del èxode; Catalá Sanz and Pérez García, Los moriscos de Cortes; Ardit, La expulsión de los moriscos; Salvador Esteban, Felipe II y los moriscos; Epalza et al., Moros y moriscos en el Levante peninsular; Bramon, Contra moros i jueus; Reglà, Estudios sobre los moriscos; García-Cárcel and Císcar Pallarés, Moriscos i agermanats.

11 García-Arenal et al., The Orient in Spain/Un Oriente español; Barrios Aguilera, La convivencia negada; García Pedraza, Actitudes ante una muerte en Granada; Gallego Burín and Gámir Sandoval, Los moriscos del Reino de Granada.

12 Cabrillana, Almería morisca.

13 Boeglin, Entre la Cruz y el Corán; Fernández Chaves and Pérez García, En los márgenes de la ciudad de Dios.

14 Aranda Doncel, Moriscos y cristianos en Córdoba and Los moriscos en tierras de Córdoba; Benítez Sánchez-Blanco, Moriscos y cristianos en el Condado de Casares.

15 Ortega López, Historia e historiografía de la expulsión; García Avilés, Los moriscos del Valle de Ricote; Vilar, Los moriscos del Reino de Murcia; Flores Arroyuelo, Los últimos moriscos.

16 Moreno Díaz del Campo, Los moriscos de La Mancha; Gómez Vozmediano, Mudéjares y moriscos en el Campo de Calatrava; Ponce Herrero, Almansa.

17 Magán and Sánchez González, Moriscos granadinos en la Sagra de Toledo.

18 Dadson, Los moriscos de Villarrubia de los Ojos.

19 García-Arenal, Inquisición y moriscos and "Los moriscos de la región de Cuenca"; Cirac Estopañán, Moriscos de Granada en la Diócesis de Cuenca.

20 Gómez Renau, Comunidades marginadas en Valladolid and La comunidad mudéjar y morisca de Valladolid.

21 Martín Benito, "Moriscos en Ciudad Rodrigo"; Sierro Malmerca, Judíos, moriscos e Inquisición en Ciudad Rodrigo.

22 Tapia Sánchez, La comunidad morisca de Ávila.

23 Martín Benito, Los moriscos del obispado de Zamora.

24 Biarnés, Els moriscos a Catalunya; Cardaillac, "Quelques notes sur la communauté morisque de Catalogne." 
In the present study we cannot enter deeply into the Morisco minority's relations with its Christian neighbors and exploiters. We know how the story ends: with the expulsion. Although a few Moriscos managed to remain by various means, and still fewer were able to return, the immense majority left Spain forever. ${ }^{25}$

We have many studies of the Moriscos who settled in North Africa, particularly in Morocco and Tunisia. Many of them harbored an understandable hatred for the country that had expelled them. ${ }^{26}$

If I do take up the Moriscos here it is because even though their forced conversion made them nominal Christians, many continued loyal - with greater or lesser intensity and authenticity - to Islam. Consequently many of these crypto-Muslims were pursued by the Inquisition, making that institution's documents one of the richest sources for studies of this population. In places like Cuenca, the Balearic Islands, and many other points in the Peninsula the grim pressures of the Holy Office revealed that some of these New Christians had not made a true conversion. ${ }^{27}$ It is equally true that many of them were really no longer Muslims, even though their Old Christian neighbors assumed that they still clung to Islam at heart.

The sacking of Morisco communities after the Christian victory in Granada resulted in tensions, open conflicts, bloodily repressed uprisings, and enslavement of the defeated rebels of 1571 . But in spite of this violence and domination some Moriscos and some Old Christians managed to coexist and even collaborate. ${ }^{28}$ We know that some sectors of Spanish society were opposed to the expulsion for a variety of reasons, a fact that explains, among other things, why not all the Moriscos were expelled and how some who did leave Spain managed to return. Those cases, few as they may seem to us, must have required collaboration and solidarity with Old Christians, even if the latter

25 García-Arenal and Wiegers, The Expulsion of the Moriscos/Los moriscos: expulsión y diáspora; Lomas Cortés, El proceso de la expulsión, El desterrament morisc valencià, El puerto de Denia y el destierro morisco, and La expulsión de los moriscos del Reino de Aragón; Bernabé Pons, Los moriscos; Marañón, Expulsión y diáspora de los moriscos; Moliner, La expulsión de los moriscos; Benítez Sánchez-Blanco, Heroicas decisiones; Lisón Hernández, "Mito y realidad de la expulsión"; Pizzi, Los moriscos que no se fueron; and the collection Destierros aragoneses, vol. 1.

26 García-Arenal, Las diásporas; Epalza and Petit, Étude sur les Moriscos andalous de Tunisie; Gozalbes Busto, Los moriscos en Marruecos.

27 González-Raymond, La Croix et le Croissant and "Les esclaves maures et l'Inquisition"; Cardaillac, Les morisques et l'Inquisition; Vidal, Quand on brûlait les morisques; GarcíaArenal, Inquisición y moriscos.

28 Dadson, Tolerance and Coexistence/Tolerancia y convivencia; Chacón Jiménez, "El problema de la convivencia." 
group's self-interest was involved. ${ }^{29}$ Further, many expelled Moriscos entered into negotiations with Spanish authorities and even collaborated with them. For example, the Moriscos of the fortress of Salé in Morocco discussed with the king of Spain the possibility of surrendering that port to his royal troops, although the talks came to nothing. ${ }^{30}$

For the purposes of our argument we must consider two factors that, while difficult to evaluate, undoubtedly carried weight at the time. One is that some exiled Moriscos kept lines of communication open with Spanish authorities with a view toward a possible return to the Peninsula, as in the case of Salé we have just described. The other is that some Moriscos until their expulsion, and some who either escaped it or returned, were more or less openly crypto-Muslim, yet that did not prevent their maintaining relations with their Old Christian neighbors that were, if not especially friendly, not openly hostile either. Though there is no question that the expulsion was an exercise in intolerance and hatred, ${ }^{31}$ it is also true that space remained for communication and negotiation between Christians (Old and New) and Moriscos (Muslims and crypto-Muslims) throughout the sixteenth and seventeenth centuries.

\subsection{Muslims, a Minority among Slaves}

As in the case of the Moriscos, there is an enormous bibliography on slavery and slaves in Spain in the Early Modern age, making it impossible to cite every pertinent source. There are studies of Spanish territory as a whole ${ }^{32}$ as well as of regions and cities all across the geography of Spain. For western Andalusia we have monographsonHuelva, Palos, Moguer, and Ayamonte, ${ }^{33}$ Cádizand Puerto Real, ${ }^{34}$

29 Dadson, "Los moriscos que no salieron" and "Asimilación, expulsión"; Soria Mesa, Los últimos moriscos.

30 Bouzineb, La Alcazaba de Buregreb and "Plática en torno a la entrega de la Alcazaba de Salé"; Sánchez Pérez, Los moriscos de Hornachos.

31 Amelang, Historias paralelas, 53.

32 Almeida Mendes, "Esclavages et traites modernes"; Stella, Histoires d'esclaves; Philipps, Slavery in the History of Spain/Historia de la esclavitud en España; Cortés López, La esclavitud negra and Los orígenes de la esclavitud negra.

33 Izquierdo Labrado, La esclavitud en la Baja Andalucía I-II; González Díaz, La esclavitud en Ayamonte.

34 Morgado García, Una metrópoli esclavista; Díaz Rodríguez, Negros y fraile en Cádiz; Izco Reina, Amos, esclavos y libertos; Parrilla Ortiz, La esclavitud en Cádiz; Torres Ramírez, La compañía gaditana de negros; Sancho de Sopranis, Las cofradías de Morenos en Cádiz. 
Seville, ${ }^{35}$ and Córdoba. ${ }^{36}$ For eastern Andalusia there are studies on Granada, Guadix and Baza, ${ }^{37}$ Málaga, ${ }^{38}$ Jaén, ${ }^{39}$ and Almería, ${ }^{40}$ for Extremadura, on the towns of Badajoz, Cáceres, Llerena, Jerez de los Caballeros, Zafra, Barcarrota, and Salvaleón. ${ }^{41}$ In the Spanish Levant there is information about Murcia, ${ }^{42}$ Valencia, and Alcoy; ${ }^{43}$ in Catalonia, on Barcelona; ${ }^{44}$ in Castile, ${ }^{45}$ on Madrid ${ }^{46}$ and Valladolid; ${ }^{47}$ and further work on Aragon, ${ }^{48}$ the Basque Country, ${ }^{49}$ and Galicia. ${ }^{50}$ Finally, there is pubished research on slaves in the island groups of the Balearics (Majorca and Ibiza) ${ }^{51}$ and the Canaries. ${ }^{52}$

It strikes us immediately that the geography of slavery overlaps to a great extent with that of the Moriscos: both groups were concentrated in southeastern Spain, to the east of an imaginary diagonal line running from Catalonia to the

35 Franco Silva, Esclavitud en Andalucía, Los esclavos de Sevilla, La esclavitud en Sevilla, and Regesto documental.

36 Salinero, Maîtres, domestiques et esclaves; Osorni-Ávila, Les esclaves de Lucena.

37 Martín Casares, La esclavitud en la Granada; Asenjo Sedano, Esclavitud en el Reino de Granada.

38 Bravo Caro, "Esclavos en Málaga"; González Arévalo, La esclavitud en Málaga and El cautiverio en Málaga; Pino, Esclavos y cautivos en Málaga; Gómez García and Martín Vergara, La esclavitud en Málaga; Vincent, "Les esclaves à Malaga" and "La esclavitud en Málaga."

39 López Molina, Una década de esclavitud en Jaén; Coronas Tejada, "Esclavitud africana en Jaén."

40 Vincent, "Les esclaves d'Almeria"; Andújar Castillo, "Del esclavo morisco al berberisco."

41 Periáñez Gómez, Negros, mulatos y blancos; Álvaro Rubio, La esclavitud en Barcarrota; Sánchez Ruano and Fernández Márquez, El fenómeno esclavista; Cortés Cortés, Esclavos en la Extremadura meridional.

42 Peñafiel Ramón, Amos y esclavos en la Murcia del Setecientos.

43 Sanchis Llorens, Aportación de Alcoy; Graullera Sanz, La esclavitud en Valencia; Cortés Alonso, La esclavitud en Valencia.

44 Martín Corrales, "La esclavitud negra en Cataluña" and "Esclavos norteafricanos"; Armenteros Martínez, L'esclavitud a la Barcelona del Renaiximent.

45 Domínguez Ortiz, La esclavitud en Castilla and "La esclavitud en Castilla."

46 Larquié, "Captifs chrétiens et esclaves maghrébins" and "Les esclaves de Madrid"; Bravo Lozano, "Mulos y esclavos. Madrid."

47 Fernández Martín, Comediantes, esclavos y moriscos en Valladolid.

48 Gómez de Valenzuela, Esclavos en Aragón.

49 Azpiazu, "La sociedad vasca ante la esclavitud" and Esclavos y traficantes.

$50 \quad$ Pérez Constanti, "Venta y manumisión de esclavos en Galicia."

51 Ferrer Abárzuza, Captius $i$ senyors de captius a Eivissa; Vaquer Bennassar, Captius $i$ renegats.

52 Trujillo Yáñez, La población esclava de Teror; Anaya Hernández, Moros en la costa; Bruquetas de Castro, La esclavitud en Lanzarote; Lobo Cabrera et al., La "otra" población; Lobo Cabrera, Los libertos en la sociedad canaria and La esclavitud en las Canarias orientales; Marrero Rodríguez, La esclavitud en Tenerife; Renshaw de Orea, La esclavitud doméstica en Canarias. 
border between Andalusia and Extremadura. Curiously, the same area corresponds with that of most immigration from the Maghreb today. ${ }^{53}$

It is essential to bear in mind that from the mid-fifteenth century to at least the second half of the seventeenth, the basic population of slaves consisted of blacks brought directly from the Atlantic coast of sub-Saharan Africa.

In Seville, for instance, of 1,902 slaves registered between 1491 and 1513, 895 were of that provenance, while North Africans totaled only 131. (The remaining 876 were of unknown origin. $)^{54}$ In the Canary Islands, of a total of 1,956 slaves sold between 1510 and 1600, 1,602 were black or mulatto while North African Muslims (called "Moriscos" in the islands) were only 243, with 121 either Indian or of unknown origin. ${ }^{55}$

In Valencia, of some 2,722 slaves registered from 1500 to 1516 , black Africans numbered 1,868 beside only 22 Muslims (the origin of the rest is unknown). In the same city, of 2,564 slaves registered by the bailiffs from 1569 to 1686,750 are identified as black, mulatto, or other mixed-race categories such as membrillos, loros, and morenos, from which we assume they were sub-Saharan Africans. Muslims formed a majority with 1,043, the rest being of unknown provenance. All in all, blacks formed the majority of the 5,284 slaves identified in Valencia in the sixteenth and seventeenth centuries: 2,168, against 1,065 Muslims. ${ }^{56}$ In Cádiz, of 9,811 slaves who were baptized between 1600 and 1699 we find 1,776 Turks, Moors, and North Africans beside 4,059 blacks and mulattos; we do not know the origin of the other $3,976 .{ }^{57} \mathrm{~A}$ second count in the same city a century later tells us that of 2,035 slaves baptized between 1700 and 1799 a mere 154 are identified as Turks and Moors. ${ }^{58}$ In Ayamonte, out of 2,181 sales of slaves concluded between 1583 and 180o, 2,073 were for blacks; the remaining 108 included some Muslims, but most were of unknown origin..$^{59}$ Of the 3,362 slaves in Huelva, Palos, and Moguer from the fifteenth to the eighteenth centuries, 1,978 were black or mulatto and 232 were Moors, the rest consisting of Indians, Canarians, and others. ${ }^{60}$ In an account of 2,837 slaves in Badajoz, Cáceres, Jerez

53 It would be interesting here to apply the concept of "Path Dependence," which studies how historical precedents influence the present even when the causes of that path dependence no longer seem to operate: Fontana, "Espacio global y tiempo profundo."

54 Franco, Regesto. The figures are calculated in Cortés López, Los orígenes, 41.

55 These figures suggest that many "ransoms" on the coast of the Sahara sought to exchange North Africans for black slaves: Lobo, La esclavitud, $142-58$.

56 Graullera, La esclavitud, 126-27, 134-35; Cortés Alonso, La esclavitud en Valencia, 58-61, and "Procedencia de los esclavos negros."

57 Morgado García, Una metrópoli, 130, 134, 146, 15 o.

58 Parrilla Ortiz, La esclavitud, 92-97.

59 González Díaz, La esclavitud, 50-51, 134-35.

6o These figures are doubtful because they come from two overlapping time periods, one from $145^{2}$ to 1765 and the other beginning in 156o: Izquierdo Labrado, La esclavitud, 1:93$96,107,115,118,125$. 
de los Caballeros, Llerena, Trujillo, and Zafra, blacks number 2,552 against only 93 Muslims, the rest being of unknown origin. ${ }^{61}$ For Barcelona, of a sample of 1,237 slaves from 1479 to 1516 we know the provenance of 1,018: 589 were black and only 294 Muslim (Moors and Turks, according to the sources). ${ }^{62}$

In other areas, however, particularly on the coasts of Valencia, Murcia, and Málaga and on Majorca, Muslim slaves formed a majority. In Majorca, of 1,869 slaves counted from 1480 to 1620, Muslims formed a majority with 1,637 (1,419 Moors, 210 Turks, and 8 Moriscos), but a mere 153 were black. ${ }^{63}$ In Málaga, in a tally of 3,576 slaves 1,437 were Muslims and 1,377 were black. ${ }^{64}$ We have two later census counts for that city from the second half of the sixteenth century: in 1578 810 slaves were registered, and it appears that 15.3 percent were Moors and 17 percent Moriscos. ${ }^{65}$ In 1581 the number of slaves was 575, of whom Muslims (North Africans, Turks, Moors, Arabs, and Moriscos) totaled 421 against only 20 blacks from Guinea; the rest were of varied or unknown origin. ${ }^{66}$ In Cartagena, of a total of 1,o99 baptized between 1640 and 1789 the majority, 707 , were Muslims while blacks numbered only 54 , the rest being of unknown provenance. ${ }^{67}$ In Madrid, out of 476 slaves we identify 184 Muslims and 53 blacks, the origin of the rest being unknown. ${ }^{68}$

For a few cities including Granada, ${ }^{69}$ Córdoba, ${ }^{70}$ Jaén, ${ }^{71}$ Valladolid, ${ }^{72}$ Cáceres, and Trujillo, ${ }^{73}$ we have not cited figures because the data related to Muslim slaves there are difficult to interpret. None of the figures cited should

61 Periáñez Gómez, Negros, 75.

62 Armenteros Martínez, L'esclavitud, 109-10.

63 The remaining 79 were "Easterners," Canarians, Jews, and Balkans: Seguí Bertran, “¿Unas islas asediadas?", chap. 12.

64 González Arévalo, La esclavitud en Málaga.

65 Bravo Caro, "Esclavos en Málaga en 1578."

66 Vincent, "Les esclaves à Málaga" and "La esclavitud en Málaga en 1581."

67 Sánchez Torres, "La esclavitud."

68 Larquié, "Les esclaves," 6o.

69 Blacks formed a majority until 1569, when they were greatly outnumbered by Moriscos enslaved after the Alpujarras War: Martín Casares, La esclavitud 91-99.

70 We have 719 documented sales of slaves between 1579 and 1621. Only 18 were white, presumably Muslims, North Africans, and Turks, though some may have appeared among the blacks and mulattos. There were also 278 Moriscos: Aranda Doncel, "La esclavitud en Córdoba."

71 A total of 250 sales involved 285 slaves between 1569 and 1574 . Most of those sold were Muslims, including 180 Moriscos, and we assume most of the 46 "others" were also Muslim: Aranda Doncel, "Los esclavos en Jaén." Between 1675 and 1685 we know of about 90 slaves of whom 57 were Muslims and 21 blacks: López Molina, "Una década de esclavitud."

72 Of 280 slaves registered in the sixteenth and seventeenth centuries 75 percent were black, while among Muslim slaves Moriscos formed a majority: Fernández Martín, Comediantes, esclavos, 129-33.

73 Of the 108 registered in both cities from the fifteenth to the eighteenth centuries the great majority were black and mulatto, with very few Muslims. Moriscos were also few, and 
be taken as definitive, in view of the nature of our documentation; further, the various monographs cited use different methods of classification and each one has nuances that require consideration. ${ }^{74}$ Table 1 provides an interesting summary of the figures given above:

TABLE 1 Origin and/or religion of slaves in Spanish cities and regions

\section{Time Period Total Blacks Muslims Others and unknown}

\begin{tabular}{llllll}
\hline Seville & $1491 / 1513$ & 1,902 & 895 & 131 & 876 \\
Barcelona & $1479-1516$ & 1,237 & 589 & 294 & 1,108 \\
Majorca & $1480-1620$ & 1,869 & 153 & 1,637 & 79 \\
Málaga & $1487-1538$ & 3,576 & 1,377 & 1,437 & 762 \\
Málaga & 1581 & 575 & 20 & 421 & 134 \\
Valencia & $1489-1686$ & 5,721 & 2,618 & 1,064 & 2, , 39 \\
Canary Is. & $1510 / 1600$ & 1,956 & 1,602 & 243 & 121 \\
Cádiz & $1600-1699$ & 9,811 & 4, o59 & 1,776 & 3,976 \\
Madrid & $1650-1700$ & 476 & 184 & 53 & 239 \\
Cádiz & $1700-1799$ & 2,035 & 1,876 & 154 & 5 \\
Ayamonte & $1583-1800$ & 2,181 & 2,073 & - & 108 \\
Huelva $^{\mathrm{a}}$ & $1560-1765$ & 3,362 & 1,978 & 232 & 1,152 \\
Extremadura $^{\mathrm{b}}$ & 16 th-18th c. & 2,837 & 2,552 & 93 & 192 \\
Cartagena $^{1640-1789}$ & 1,099 & 54 & 707 & 238 \\
\hline
\end{tabular}

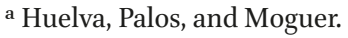

b Badajoz, Cáceres, Jerez de los Caballeros, Llerena, Trujillo, and Zafra.

Sources: Franco, Regesto; Lobo, La esclavitud, 142-58; Graullera, La esclavitud, 126-27, 134-35; Cortés Alonso, La esclavitud en Valencia, 58-61; Morgado García, Una metrópoli, 130, 134, 146, 150; Parrilla Ortiz, La esclavitud, 92-97; González Díaz, La esclavitud, 50-51, 134-35; Izquierdo Labrado, La esclavitud, 1:93-96, 107, 115, 118, 125; Periáñez Gómez, Negros, 75; Armenteros Martínez, L'esclavitud, 109-10; Seguí Beltrán, “¿Unas islas asediadas?”; Vincent, "Les esclaves à Málaga” and "La esclavitud en Málaga”; Sánchez Torres, "La esclavitud en la Cartagena." for Madrid: Larquié, "Les esclaves"; González Arévalo, "La esclavitud," 67
}

tend to disappear from the record after the Granadan War: Aragón Mateos and Sánchez Rubio, "La esclavitud en la Alta Extremadura."

74 The provenance of slaves is difficult to establish, since historical sources do not always provide that information. Further, some authors classify them by their place of origin while others use criteria such as skin color or entry through a given port city. Therefore the figures in Table 1 are mere estimates that may be improved through better interpretation of the original documents, something beyond the scope of the present work. 
In spite of the cautions we have mentioned, it is clear that slaves from south of the Sahara were dominant throughout the Early Modern period. Of the more than thirty-eight thousand slaves documented, black Africans made up almost twenty thousand, while Muslims were somewhat over 7,500. We see that more than eleven thousand were American Indians, Asians, Europeans, and others, those of unknown origin being the most numerous. In short, there were many more slaves from black Africa than North African Muslims, even if we assume that some of the former had embraced Islam already.

We should pay attention to regional differences, however, since everything indicates that at certain times and places Muslims outnumbered black Africans. In Granada, for instance, we can see that black slaves dominated until 1569, when they were displaced by the large number of Moriscos enslaved after the Alpujarras rebellion. ${ }^{75}$ In Málaga the Muslim slave majority arose first from the conquest of the Kingdom of Granada, then from the Spanish offensive on the North African coast (from the seizing of Oran in 1509 to that of Tunis in 1535), and finally from the crushing defeat of the Alpujarras in $1571 .^{76}$ In Jaén, out of ninety slaves bought and sold from 1675 to 1685 there were sixty-four Muslims and only twenty-six blacks and mulattos. ${ }^{77} \mathrm{I}$ have not included Murcia in Table 1 because we have only one document consisting of seventy-eight slave sales: the few blacks and mulattos listed were captured in Oran or by corsairs at sea, and only one is clearly linked to the Atlantic slave trade in black Africans. ${ }^{78}$

These cases, however, do not invalidate the fact that the immense majority of slaves in Spain in Early Modern times came from sub-Saharan Africa. As we noted above, A. Stella estimated their total number at two million, of whom only three or four hundred thousand would have been Muslims (including the Moriscos enslaved after ${ }^{1570}$. ${ }^{79}$ It is risky to accept these figures, since our knowledge of slaves and captives from the sixteenth to the eighteenth centuries is so uneven and our information is still fragmentary and of varying quality. Some kinds of sources, like baptismal and marriage records, contain data on Maghrebis, Easterners, and blacks, but death notices usually do not. While

75 Martín Casares, La esclavitud en la Granada, 91-99.

76 Bravo, "Los esclavos"; González Arévalo, La esclavitud en Málaga; Vincent, "Les esclaves à Málaga" and "La esclavitud en Málaga."

77 López Molina, Una década de esclavitud, $135-38$.

78 Peñafiel, Amos, 39-52.

79 Although it is hard to trust such estimates completely, a point of departure can be Stella, Histoires d'esclaves, $7^{8-79 .}$ 
almost all black slaves eventually became Christian only a minority of Muslims did so, explaining the preponderance of blacks in baptismal records.

Maghrebi slaves have been relatively invisible to historians in comparison to black Africans, who arrived in such huge numbers by the Atlantic route from the Gulf of Guinea and nearby regions. The late eighteenth century also saw a surge in black slavery as Spain took a more active role in the slave trade while it was legal, from 1789 to 1817 , and especially afterward in its illegal form $(1821-1866){ }^{80}$

Even a brief review of the data about Muslim slaves in the sixteenth, seventeenth, and eighteenth centuries will show how difficult it is to estimate their numbers. In the sixteenth century the chief source for North African slaves was the Spanish conquest of Maghrebi ports; our first point of reference, therefore, is Spanish expansion into North Africa from the conquest of Melilla (1497) up to the final loss of Tunis (1574). When a city was conquered some or all of its residents would be enslaved: Oran yielded eight thousand slaves, and Bougie and Tripoli a total of eighteen thousand. ${ }^{81}$ Those victories - the conquest of Tunis in 1543 is one example - brought so many slaves into the Peninsular market that prices for them fell sharply. ${ }^{82}$

A second source of slaves was the many raids launched from Spanish strongholds and the Canary Islands onto the nearby coasts of North Africa and the Sahara, respectively. We know that between 1510 and 1594 at least 154 armed slave-seeking expeditions left the Canary Islands: eighty-seven from Fuerteventura, fifty-nine from Gran Canaria, and eight from Lanzarote. Together they captured more than ten thousand Africans. ${ }^{83}$

The third factor was the squadrons of royal galleys belonging to the Monarchy: those of Spain, Naples, and Sicily as well as the Armada of the Ocean Sea (which, though its chief mission was to protect the route to the Indies, also served as a virtual corsair fleet in the Strait of Gibraltar). These ships captured many enemy vessels with their crews, and also landed troops in various North African ports, sacking them and enslaving many of their inhabitants. ${ }^{84}$

8o Martín Corrales, "La paulatina desaparición," "La esclavitud negra en Cataluña," and "La esclavitud en la Cataluña."

81 Domínguez Ortiz, La esclavitud, 7 .

82 For the increased number of slaves in Málaga after the conquest of Tunis see Bravo Caro, "El municipio de Málaga." For the arrival of North African slaves in Valencia after the conquest of Oran, Bougie, and Tripoli see Cortés Alonso, La esclavitud, 297-421.

83 Lobo, La esclavitud, 66-69, 142.

84 Lomas Cortés, "L'esclave captif" and "Les galériens du Roi"; Serra Puig, "Galeres catalanes." 
In fourth place were private corsairs who also engaged in the capture of slaves, especially in the sixteenth century. ${ }^{85}$ In subsequent centuries their activity in this area declined sharply.

A fifth source was the creation of small defensive flotillas (often consisting of only one or two ships) to protect certain points along the Spanish coastline. These managed to make a number of captures, by the initiative of either local authorities or nearby residents. ${ }^{86}$ There were also defenses on land against North African corsairs who came in search of slaves and booty, by which the invaders were often seized and enslaved themselves. ${ }^{87}$ The same fate awaited Muslim corsairs who were shipwrecked on the Spanish coast.

The sixth and final factor was the enslavement of most of the Moriscos defeated and captured after the Alpujarras War of 1568-1570. Although these were nominally Christian, in fact their presence added considerably to the number of slaves who can be counted as Muslim. ${ }^{88}$

At the present state of our knowledge it is very risky to estimate how many Muslim slaves lived in Spain in the sixteenth century. The figure for Majorca can be considered virtually definitive, since it is based on documentation from all over the island - administrative, municipal, ecclesiastical, and royal: about 1,419 North Africans, 210 Turks, and eight Moriscos, for a total of 1,869 slaves between 1480 and $1620 .{ }^{89}$ The same can be said for the Canary Islands, whose inhabitants captured about ten thousand slaves in the 150os, some through raids on the Saharan coast and many others through ransoms negotiated with North Africa; only 243 were Muslims, however. ${ }^{90}$ For Málaga we have the figure of 1,437 Muslims (North Africans and Turks) between 1487 and $1538 .{ }^{91}$ In the

85 Alonso Acero, España y el Norte de África; García-Arenal and Bunes Ibarra, Los españolesy el Norte de África; Seguí Beltrán, “¿Unas islas asediadas?”.

86 For Catalonia see Serra Puig, "Galeres catalanes"; for the galleys of Denia, Lomas Cortés, "Las galeras de Denia”; for the Balearic Islands, Seguí Beltrán, “¿Unas islas?”.

87 For the Balearics see Seguí Beltrán, “¿Unas islas?”, chap. 12. There are many reports of North African corsair ships and their crews being captured after a wreck on the Spanish coast. In 159630 corsairs were taken when their galliot ran aground on the beach at Cádiz: Tarruell, "Circulations," 134. In 1692 after an Algerian ship foundered off Majorca several of its crewmen were seized: Vernet Ginés, El rescate del arráez argeli Bibi.

88 Garrido García, "La esclavitud morisca" and "La esclavitud en el reino de Granada”; Martín Casares, La esclavitud en Granada; Vincent, "Les esclaves d'Almeria”; Andújar Castillo, "Del esclavo morisco al berberisco"; Cabrillana, "Esclavos moriscos en la Almería."

89 The remaining 140 were blacks (from either North Africa or the Guinean coast), Easterners, Canarians, and Jews: Seguí Beltrán, “¿Unas islas asediadas?”.

$90 \quad$ Lobo, La esclavitud, 66-69, 142-58.

91 More than 450 slaves arrived there after Spain conquered Oran: González Arévalo, $L a$ esclavitud, $57-58,67$. 
1578 census only one-third of slaves were North Africans and Moriscos, while in the census of 1581 they numbered 421 out of a total of $575 .{ }^{92}$

Our other information is very fragmentary, emerging from bills of sale and baptismal registers in a variety of places. One would have to weigh its significance at each specific site, comparing the figures for Muslims with those for slaves as a whole, a task that goes beyond the present study. Here we will simply mention some scattered notices: in Seville, 131 Muslims between 1453 and 1513;93 in Barcelona, about 294 between 1479 and 1516;94 in Valencia, we saw that there were about 1,064 in the sixteenth and seventeenth centuries. ${ }^{95}$ In Valladolid there were forty to sixty at the same period; ${ }^{96}$ in Huelva, Palos, and Moguer, only 232 between 156o and 1765, and there were hardly any in Ayamonte. ${ }^{97}$ In Extremadura only 93 are found out of a total of $2,837^{98}$ (see Table 1). At the moment it seems useless to combine these into a total of Muslim slaves, since the result would be a reduced and incomplete number. And all the figures offered should be treated with caution since scholars, using several kinds of documentation, have applied different criteria for classifying slaves.

In the seventeenth century the chief source of Muslim slaves was corsair activity by the king's ships, though it does not seem to have been very efficient. Raids from Spanish presidios like Oran, Melilla, and Ceuta and from the Canary Islands diminished in both frequency and the number of captures. As time went on Spain increasingly gained slaves by seizing Muslim ships that prowled the Spanish coasts, detaining Maghrebi corsairs who came ashore in Spain to raid, and arresting the victims of shipwrecks. Spanish privateers pursued and caught French, English, and other European vessels when those countries were Spain's adversaries in war. Muslim targets were not as desirable, since the ships' cargoes had less value; most slaves taken from them were sold in Livorno and Malta. ${ }^{99}$

\footnotetext{
92 Bravo Caro, "Esclavos en Málaga”; Vincent, "Les esclaves à Málaga" and "La esclavitud en Málaga"; González Arévalo, la esclavitud.

93 Franco, Regesto, 41.

94 Armenteros Martínez, L'esclavitud, 109-10.

95 Graullera, La esclavitud, 126-27, 134-35; Cortés Alonso, La esclavitud en Valencia, 58-61.

96 Fernández Martín, Comediantes, esclavos, 129-34.

97 In Izquierdo Labrado, La esclavitud, v. 1, there are differences in the calculated total for the period $145^{2-1765}$ (p. 125) and the figures for each individual century in the preceding pages $(93-96,107,115,118)$, since the data for the sixteenth century begin in 1560 . For Ayamonte see González Díaz, La esclavitud, 50-51, 134-35.

98 Periáñez Gómez, Negros, 75 .

99 López Nadal, El corsarisme mallorquí.
} 
Our information from the Balearic Islands is scattered. From 1620 to 1659 we know of only twenty-five Muslim corsairs captured. ${ }^{100}$ We know more about the participation of privateers in the second half of the century: although most attacks were made against European vessels, Balearic privateers captured at least 976 Muslims between 1652 and 1698: 654 by captains from Majorca, 274 from Ibiza, and forty-eight from Minorca. ${ }^{101}$ These figures should be considered a minimum, since we do not know the total number of ships seized or the number of crewmen and passengers in each one. We cannot simply add these figures to our data about sales, purchases, baptisms, legal suits, escapes, and manumissions involving Muslim slaves in the islands during the 16oos.

For Catalonia we have reliable information on the number of Muslim rowers in the galleys of the Catalan squadron from the late sixteenth to the early seventeenth centuries, though the total is not large. ${ }^{102}$ There was a surge in captures in the late 16oos when several Catalan coastal towns armed their own galleys. ${ }^{103}$ In 1685 a galliot from Barcelona caught two frigates off Sitges that carried forty-five "Moors from Algiers"; these were sold to a Genoese for 3,06o piasters. ${ }^{104}$ In 1687 a polacre under the king's flag entered Barcelona's port with eighteen Moors, who were bought by the French and sent to Marseille. ${ }^{105}$ In 1700 sixteen Algerians were captured in Tossa and eventually sold to a Genoese, ${ }^{106}$ while in 1702 forty Algerians were sold to various merchants. ${ }^{107}$

100 Vaquer Bennasar, Captius i renegats, 32.

101 The basic source is López Nadal, El corsarisme mallorquí. There are more limited data in González-Raymond, La Croix et le Croissant and "Les esclaves maures"; Fajarnés, "Una presa del Capitán Calafat," $1-2$.

102 In the seventeenth century Muslim slaves made up about 20 percent of rowers, which grew to one-third: Heras Santos, "Los galeotes."

103 For the early seventeenth century see Serra Puig, "Galeres catalanes"; for its end, Martín Corrales, "Impulso de la actividad marítima."

104 In the sea battle one Muslim captain and four Turks were killed. The French consul in Barcelona tried to buy the slaves for his country's galleys and petitioned Madrid to be allowed to take them out of the country, but he did not receive authorization: see letters from the consul dated 16 June, 4 July, and 14 July 1685: Archives Nationales, Paris, Affaires Étrangères, B-I, 178 , fols. $76-79$.

105 The king's polacre sank off Montjuich. When local residents saw the Turks aboard "it was an occasion for the populace, who saw only Turks on deck, to hurl themselves on the vessel and steal whatever they could." An order to return the stolen goods on pain of excommunication was ignored. The 18 Turks, already sick, were held in unhealthy quarters and some of them died, while the survivors were bought and conveyed to Marseille in a tartane: ANP, AE, B-I, 178, fols. 98-102; letters from the French consul in Barcelona dated 26 January, 2 March, and 27 April 1687.

106 ANP, AE, B-I, 178, fols. 201-O3; letter from Soleil, 14 March 1700.

107 In the French consul's opinion "This was not a great matter except for three or four whom the King of Spain took as his own by right": ANP, AE, B-I, 178, fol. 270; letter from Soleil, 4 June 1702. 
For Andalusia we have a census of the Muslim slaves who were living in Puerto Real in 169o, drawn up in anticipation of a visit from a Moroccan ambassador who could arrange exchanges for Christian captives. ${ }^{108}$ At about the same time there was increased activity in the market for North African slaves in Seville. ${ }^{109}$

For the remaining Spanish territories we must resort to registers of sales and purchases, baptismal records, and other kinds of civil documents. We have noted that in Cádiz at least 1,776 baptisms of Muslims were registered in the 16oos; ;10 in Valencia, 1,043 from the mid-sixteenth to the late seventeenth centuries; ${ }^{111}$ and in Huelva, Palos, and Moguer, seventy. ${ }^{112}$ While we have some data on Muslim slaves in other places it is very difficult to establish their number for Extremadura, ${ }^{113}$ Valladolid, ${ }^{114}$ Jaén, ${ }^{115}$ and Madrid. ${ }^{116}$

We know a good deal about Muslims who served in the royal galleys in the sixteenth and seventeenth centuries. ${ }^{117}$ These ships reserved about one-fifth to one-third of their benches for Muslim slave oarsmen, and did not always obtain them by capturing enemy corsair ships: in Majorca there were domestic slaves who committed crimes and were condemned to the galleys. ${ }^{118}$ Still, many men did come from ship captures: between 1682 and 1697 the Mediterranean galley squadron seized at least eight Muslim ships that yielded 302 slaves. ${ }^{119}$ Because in the present state of our knowledge it is risky to estimate the total number of Muslim galley slaves in Spain in the sixteenth and seventeenth centuries, we shall not do so at this time.

While there are somewhat fuller data for the eighteenth century, it is still hard to estimate how many Muslim slaves lived in Spain. Only one military operation in that period, the Spanish conquest of Oran in 1732 (the Algerians had taken it in 1708), brought in a good number of slaves. In the other Spanish presidios in North

\footnotetext{
108 Izco Reina, "El censo de moros."

109 Santos Cabota, "El mercado de esclavos berberiscos."

110 Morgado García, Una metrópoli, 130, 134, 146, 15 o.

111 Graullera, La esclavitud, 126-27, 134-35.

112 Izquierdo Labrado, La esclavitud, 1:115.

113 Periáñez Gómez, Negros, 75-93.

114 Fernández Martín, Comediantes, esclavos, 129-34. When the Persian ambassador Hussein Ali Beg arrived in Valladolid in 1601 he was assigned a Turkish slave who tried to assassinate a member of his retinue who had converted to Christianity: Don Juan de Persia, Relaciones, and the Alonso Cortés ed.

115 López Molina, Una década de esclavitud.

116 Bravo Lozano, "Mulos y esclavos"; Larquié, "Les esclaves de Madrid."

117 Lomas Cortés, "L'esclave captif" and "Les galériens du Roi."

118 For Majorca see Seguí Beltrán, "La pena de galeras en Mallorca."

119 Martínez Martínez, "Los forzados de Marina," 86.
} 
Africa there were attacks in reprisal for earlier ones, but fewer slave-catching raids like those undertaken in the two previous centuries. ${ }^{120}$

The large number of corsair captures arose from the new naval policy initiated by Bourbon ministers, especially from the mid-17oos onward. Under the Marquis of Ensenada a new fleet was built that was able to combat North African corsairs, made up essentially of ships of the line and squadrons of xebecs and assisted by a good many privateers, some of whose captains joined the royal Armada. ${ }^{121} \mathrm{~A}$ royal decree also granted rights to those who captured enemy privateers and license to sell them on the open market, exempting them from paying the thirty ducats that the Crown charged for each slave it wanted for its own galleys. ${ }^{122}$ In battles at sea Spanish corsairs captured 8,439 Muslims alive, while 1,264 died in the fighting when their ships were seized. ${ }^{123}$ Along the Catalan coast 949 North African corsairs were made captive between 1721 and 178 o, of whom 181 died in battle. ${ }^{124}$

The complete cessation of slavery was achieved only after a series of peace treaties between the Spanish Monarchy and other rulers: with the Sultan of Morocco (1767), the Ottoman Caliph (1782), the Bey of Tripoli (1784), the Dey of Algiers (1786), and the Bey of Tunis (1791). Article 13 of the Spanish-Moroccan Peace Treaty of 1767 stipulated that officers, soldiers, and sailors captured in war would be considered "prisoners," since "His Moroccan Majesty wishes to erase from the memory of men the odious name of slavery." Old people, women, and children would be set free at once. ${ }^{125}$ The same language was repeated in the later treaties with the Ottomans, Tripolitans, Algerians, and Tunisians.

We conclude from the above that the entity most directly concerned with the capture and possession of Muslim slaves in the Early Modern age was the monarchy. It employed them chiefly in the galleys of the royal fleet, but when those fell out of use it diverted them to public works such as the mines at Almadén, the naval shipyards at Cádiz and Cartagena, hospitals, and new roads. Still, from the late 16oos and early 170os the crown's principal concern was the exchange of captives and/or prisoners. The original impulse was probably to free Spaniards from the garrisons at Larache and Oran, seized respectively by

120 Galindo y de Vera, Historia, vicisitudes, esp. Part 4.

121 The reform of the Spanish Armada was not a success in its rivalry with England, France, and other European powers. But it did help to persuade the North African regencies to sign treaties with the Spanish Monarchy: Merino Navarro, La Armada Española en el siglo XVIII.

122 Domínguez Ortiz, Sociedad y Estado, 338.

123 Barrio Gozalo, Esclavos y cautivos, 144-45.

124 Martín Corrales, "Esclavos norteafricanos," 383.

125 Cantillo, Tratados, 687. 
the Moroccans in 1689 and the Algerians in 1708. All our sources indicate that the aim continued in force throughout the eighteenth century.

In contrast, private individuals do not seem to have cared particularly to arm vessels against the Muslims. During the period when the largest number of Muslim prisoners were taken, those enslaved were sold to the French, the Genoese, or directly in Livorno or Malta. That was certainly the case in Majorca in the second half of the seventeenth century and in Catalonia throughout the ${ }^{1700 s .}{ }^{126}$ Most North Africans were captured along the Spanish coast, whether by royal fleets or by ships armed by local initiatives to combat the menace of enemy corsairs.

To the extent that exchanges, ransoms, and manumissions did not keep pace with captures, the crown throughout the eighteenth century could count on a few thousand slaves that it set to work in the galleys, shipyards, Almadén mines, and road construction. The number of Muslim galley slaves remained steady at about one thousand until they were discontinued in $1748 ; ;^{127}$ from 1700 to 1733 about 1,373 of them occupied the rowers' benches, constituting 16 percent of all rowing crews. ${ }^{128}$ Of these 1,10o had been captured by royal ships, 19 o had been purchased, and thirty came from ransoms: that is, they were slaves bought in order to set other rowers free (twenty-five were exchanged, seventeen replaced, and two condemned.) $)^{129}$ In 1740 there were 585 slaves assigned to the seven galleys in the royal fleet, 114 of whom were released as too old or ill to work. ${ }^{130}$

It appears that the largest number of slaves was employed in naval shipyards: in 1766, of 1,453 royal slaves there were 906 working in Cartagena, eighteen in Cádiz, and five in El Ferrol. Building the road over the Guadarrama Mountains employed 230; 265 worked on a road in Catalonia; and twenty-nine captains and first mates helped build the Segovia-to-Lleida road. ${ }^{131}$ Slaves worked in the Almadén mines from at least $155^{\circ} .^{132}$

126 Although its focus is privateering against the English, see the relevant work in this regard by Martínez Shaw, "Un mal negocio." For the Balearics see Martín Corrales and López Nadal, "Entre la iniciativa privada"; also López Nadal, El corsarisme mallorquí.

127 Barrio Gozalo, "La esclavitud."

128 Martínez Martínez, Los forzados de Marina, 103.

129 Martínez Martínez, Los forzados, 106.

130 In that year there were only 471 Muslim rowers available although 500 were needed: Martínez Martínez, Los forzados, 51.

131 Barrio Gozalo, Esclavos, 146, and "La mano de obra esclava”; Martínez Martínez, Los forzados. About twenty Moorish slaves made a failed attempt to escape and were then assigned to work on water pumps, but they all died in a short time: Casal Martínez, "La audacia de los esclavos"; Domínguez Ortiz, Sociedad, 338 .

132 Gil Bautista, Las minas de Almadén, 152-58; Benítez Sánchez-Blanco, "Esclavo del rey." In 1632 an owner from Cáceres sold a "young male North African slave, twelve or thirteen 
The more important prisoners, ship's captains and first mates, were held in several places including the castle of Santa Catalina in Cádiz, the Alhambra in Granada, the Alcázar in Segovia, and the castle of Lleida. In principle most were not required to work, though sometimes the reality was different. Two prominent captains taken in 1751 were sent to the Alhambra, while three more captured in 1761 were confined in Santa Catalina in Cádiz. The authorities feared that wealthier captains and other slaves might bribe their jailers to escape, so five who had been in Cartagena and two from the Alhambra were transferred to the Alcázar of Segovia as a more secure prison. By 1764 their number had increased to eighteen and they were sent on to Lleida; four years later that group and others from Segovia were moved to Cartagena in preparation for an exchange with Christian captives. In 1769 thirteen captains and first mates were dispatched from Málaga, Cartagena, and Cádiz to Segovia. There the number of prisoners peaked at fourteen, though by 1781 only two remained. The governor of the Alcázar declared that "when the Court is at San Ildefonso, the courtiers like to come and see them and they must appear decent."133

In fact there was no strong impulse to maintain Muslim slaves in the eighteenth century, as we can show through a few examples. At times of plague in North Africa, Spanish ships would protect themselves from infection by sinking captured corsair ships along with their crews. ${ }^{134}$ In 1757 a ship commanded by the Catalan captain Balanzó destroyed an Algerian frigate in combat but sailed away from its forty-three survivors, who were picked up later by private boats from the nearby port of Palamós. ${ }^{135}$

In considering the treatment that Muslim slaves or captives received on Spanish soil we must bear three factors in mind. First, the slave had a value for sale or exchange - in short, he was merchandise - and therefore his life had to be preserved, in good condition if possible. In 1576 the residents of the village of Casares in Málaga, after catching the captain of a North African brigantine that had foundered on the coast while escaping the Galleys of Spain, threw him off a tower. The authorities strongly disapproved, since the captain could have brought a good ransom. ${ }^{136}$

Second, captives interacted with Christian society in a great many ways that depended on social class and the nature of the individuals who owned them

years old, who was sold to the Fúcars for [work in] Almadén for thirty thousand maravedís because he had grown disobedient and troublesome": Periáñez Gómez, Negros, 401.

133 Barrio Gozalo, Esclavos y cautivos, 139, 142-44.

134 Barrio Gozalo, Esclavos, 138.

135 Barrio Gozalo, Esclavos, 141; Martín Corrales, "Esclavos norteafricanos," 381.

136 Cited in Tarruell, "Circulations," 135, based on Lamoine and Planas, Entre traces mémorielles. 
or whom they encountered. It was possible to gain one's freedom, and there was the option of conversion to Christianity (about which more below), even if some degree of coercion was involved.

Third, slaves could not be mistreated too severely. Information circulated widely in the Mediterranean, and authorities in slave-holding countries had to control their prejudices and behave with a certain moderation; if one side pressured or abused its slaves, the other could take severe reprisals. In the "Monroy Affair" of 16o9-1622, an Algerian was unable to ransom his daughter, who had been forcibly converted to Christianity in Corsica; Algiers took revenge against three Trinitarians from Castile, who died in prison. Relations between Spain and Algiers deteriorated sharply as a result. ${ }^{137}$

The Algerian captain Bibi Muhammad, an expert and dangerous corsair, was captured when his ship went down off Majorca. The island's Viceroy was reluctant to have him exchanged or ransomed, because

it will disappoint local residents to be robbed of these slaves, the fruit of their expeditions and the very reason they undertake them, for they use them to exchange for any Majorcans who might be captured (as often happens, Algiers being so near and the Algerians so often raiding). That could discourage [our own] corsairs and make them reluctant to pursue them any more, which would be a great disservice to His Majesty and contrary to the public good. ${ }^{138}$

137 For the whole episode see Hershenzon, The Captive Sea, 54-55, 114-15, 163-68, 172-74, 177. Tarruell, "Circulations," 162.

138 " $\mathrm{N}]$ o dejará de causar algún desconsuelo a aquellos naturales el que se los despoje de estos esclavos que es el fruto de sus corsos y el fin con que salen a ellos, con los quales suelen hacer canje si sucede el cautivar algunos mallorquines, que con la vecindad de Argel y corsos que también practican los argelinos sucede muchas veces, lo que podría influir en desaliento de los mismos corsos y que en adelante se entibiasen en salir a ellos, lo que seria un gran deservicio de Su Majestad y contra el beneficio de la causa pública." The Viceroy went on to say that "this Moor is a very great corsair, very active on these coasts and those of Catalonia, where he has taken many prizes. For beside his long experience he is very brave, bold, and enterprising, and above all very intelligent and clever in both seafaring and corsair warfare, and capable of taking on any important adversary" ("este moro es un gran corsario, muy práctico en estas costas en las cuales, y en las de Cataluña, tiene hechas muchísimas presas, porque a más de su gran practica, es muy valiente, muy arrojado y atrevido y sobre todo muy inteligente y sagaz, así de la marinería, como del modo de hacer los corsos, y capaz de emprender cualquier facción grande"): Vernet Ginés, El rescate, xi-xiii, quotation at xi. 
The captain, who was also known as Robacols or Robacoles, had been acquired by the fishermen's guild of Palma de Mallorca. He wrote several times to Algiers claiming to be badly treated, and one of his letters was intercepted by the Spanish authorities:

I have lived with them for three years, the entire time chained on a flat roof with a ring around my neck and shackles on my feet, suffering great hunger and thirst. And because they have me in this prison I have not been able to learn if any of your letters have come for me, or when. ${ }^{139}$

Nonetheless he managed to get some letters through to his family, who informed the Dey of Algiers and interested him in Bibi's ransom. Bibi also found allies among the clergymen who oversaw the bagnios where Christian slaves were held. In April 1692 these wrote to the Viceroy, describing how slaves in the Regency of Algiers were treated:

In this city they allow slaves to come to church and attend the holy sacraments, and on feast days their owners send them out to fulfill their Christian duties. They do not force anyone to abandon the Christian religion; they invariably treat them well; and if any slave complains to the Governor that his owner mistreats him, they punish [the owner] and make him sell the slave to someone else. So, excellent Sir, why do Spaniards mistreat or force [their slaves], when as you know, soldiers of Christ wish to proceed with kindness? If we do not do so, these infidels seize the chance to act badly toward these poor slaves and toward us; for although we are free it breaks our hearts to see our churches shuttered and our brothers ill-used.

Things changed after news (whether real or exaggerated) of Bibi's ill-treatment arrived:

We have had a great misfortune because they have closed all of our churches and put every slave from the island of Majorca in chains: all because a Turk, the captain of a settee who is called Biue Maamet Rex, a captive in Majorca, writes to the Governor of this city and royal house

139 " $[\mathrm{H}] \mathrm{e}$ vivido tres años y he estado en ellos sobre un terrado con una argolla en el cuello y grillos en los pies y gran hambre y sed, y por estar encarcelado en esta prisión en que me mandaron poner no he podido saber cuando vinieron las cartas de vosotros, o si las tuviese o no": Vernet Ginés, El rescate, 25-26. 
that he is enslaved to a fisherman's wife who (according to what he writes) must be ferocious. She will not let him practice his religion, gives him nothing to eat, and keeps him chained by the neck at night, and he also complains of how badly the other slaves are treated.

\section{Therefore the friars asked the Viceroy of Majorca to treat the Algerian slaves}

with love and charity, so that in this city we Christians will be treated in the same way and not feel the pain of being afflicted and ill-used, and worst of all without churches and sacraments. ${ }^{140}$

After hearing this news the Viceroy ordered the captain transferred to the city prison. His owners, the fishermen's guild, were required to pay one real a day to ensure he had proper food. When they asked permission to sell Bibi to the galleys the Viceroy declined, "because it seemed to me that this new punishment and pressure could harm the poor Christian captives in Algiers." ${ }^{141} \mathrm{He}$ also visited the captain in prison, where "this Moor came forth to thank me for what I had done on his behalf, and to show his gratitude he offered to send new letters to Algiers describing the changes that had been made and how well they were treating him." The Viceroy sent that information to the king and the Council of State to be conveyed to the Trinitarians in Algiers, so they

140 "En esta ciudad permiten a los esclavos que vengan a las Iglesias, que frecuenten los Santos Sacramentos, y en los días de fiesta sus mismos patronos los envían a que cumplan con la obligación de cristianos; no fuerzan a nadie a que deje la Religión Cristiana: los tratan uniformemente bien: y si alguno se queja ante el Gobernador de que su dueño lo maltrata, le castigan y se lo hacen vender a otro, pues que razón obra Señor excelentísimo que los españoles maltraten ni fuercen, cuando los soldados de Cristo son voluntarios como V.E. sabe, para que nosotros no obremos con suavidad, y especialmente cuando con lo contrario se da ocasión a estos infieles a que hagan lo mismo con estos pobres esclavos y con nosotros, que aunque libres, sentimos en el corazón ver cerradas nuestras Iglesias, maltratados nuestros hermanos. ... [H]emos tenido un gran pesar por cuanto nos han cerrado todas las iglesias y puesto en cadenas todos los esclavos de la Isla de Mallorca: por cuanto un turco, capitán de una saetía que se llama Biue Maamet Rex, cautivo en Mallorca, escribe al Gobernador de esta Ciudad y Casa del Rey como se halla esclavo en poder de una mujer de un pescador que, según las cosas que escribe debe ser una fiera, que no le deja vivir en su ley, que no le da de comer, que de noche lo tiene con una cadena al pescuezo: quejase también del mal trato de los demás esclavos. ...[C]on amor y caridad, para que en esta ciudad hallemos los cristianos la misma correspondencia y no tengamos el desconsuelo de vernos afligidos y mal tratados, y lo más sensible, sin Iglesias y sin Sacramentos": Vernet Ginés, El rescate, 21-24.

141 "[P]areciéndome podía esta nueva vejación y apremio redundar contra los pobres cautivos cristianos en Argel": Vernet Ginés, El rescate, 23-24, 28-29. 
could inform the Dey in the hope that "with this, the poor Christian captives may find relief."

The Dey of Algiers, for his part, took a keen interest in obtaining Bibi's freedom through an exchange or ransom. ${ }^{142}$ This case became entangled with the matter of a captain Hassan, a rower in the Galleys of Sardinia, because Cristóbal Mateu, a Valencian slave in Algiers, had been freed after promising to ransom Hassan. When time passed without any action by Mateu, however, the Dey took his revenge by seizing the first Valencian who arrived in the port of Algiers: it was Carlos Vidal, a boatswain who "was on an [English] ship traveling under safe-conduct." The Dey offered to exchange both Vidal and a Spanish noble, Raimundo de San Martín, for Bibi and Hassan.

When no exchange had been made by 1694, the Dey once more ordered all the Majorcan slaves in Algiers into prison, making sure that the news would reach Spain to put pressure on the authorities there. Fray Pablo Garriga, who was in the city at the time, wrote a letter at the Dey's behest stating that "because of this captain, all the Majorcans are in prison and three who were free out of charity have been arrested, every day with new and extraordinary punishments." He believed that the Dey would not set any Majorcan free "either by exchange or for money." 143 A second letter in Arabic from the Dey himself to the Viceroy of Majorca repeated these terms. ${ }^{144}$

Finally, the Viceroy of Majorca and the Council of State convinced the king of Spain to agree to exchange Bibi and Hassan for Carlos Vidal and Raimundo de San Martín. The exchange was made before the end of $1694 .{ }^{145}$

Cases such as these continued into the eighteenth century: sources show how complaints by Muslim slaves in Spain had negative repercussions for Christians in the bagnios of Algiers, and vice-versa. Such laments, and the efforts by authorities on both sides to ensure comparable treatment of the enslaved, are documented for $1758,1759,1761,1762$, and 1766.146

We could cite many more examples. Clearly, poor treatment of slaves on one shore of the Mediterranean found an echo on the other; but authorities on both sides, while forced to carry out some reprisals, tried to limit their severity. Further analysis is needed to determine how "reasonable" each side was prepared to be in applying this kind of pressure.

\footnotetext{
142 Vernet Ginés, El rescate, xii-xiii.

143 Vernet Ginés, El rescate, 42.

144 Vernet Ginés, El rescate, 37-40.

145 Vernet Ginés, El rescate, xix.

146 Barrio Gozalo, Esclavos y cautivos, 176-82.
} 
We have mentioned above how slaves had to be provided with the basic necessities of shelter, food, and clothing, however scanty or deficient. We have several examples of the attention received by crews of Muslim corsair ships that were captured and brought into Spanish ports. ${ }^{147}$

One of the most vivid examples of the kind of medical and other assistance that captured corsairs received occurred in Barcelona in 1754. An Algerian pink with fifty-nine crewmen aboard was seized, though six died when the boat taking them to shore capsized. Confined in the lazzaretto, the men spent two days in their original clothing, though that should have been burned immediately and they should have been bathed and supplied with clean clothes. The scene of quarantine was chaotic: the soldiers guarding the Algerians insulted the doctor from Barcelona's Board of Health because they had not been paid. Meanwhile the local governor insisted on feeding the prisoners with wheat from their own ship, even though it had gone bad; many fell ill and complained of stomach pains. The governor yielded and sent them some beans, believing that "that has made them happy," but they continued to complain of a lack of firewood or oil for cooking the food. The doctor requested a cartload of straw because the building was so cold in the mornings. Other quarantined men began to suffer from various ailments: one had a fever and it was thought that "since he came from the mountains" and had had a fright when his shipmates drowned, he had turned "melancholy." Another's head injury had become infected. A third man suffered from "a swelling and was heated," so the doctor dosed him with "mercury pills": "in recent days this Moor complained that he had some slight pains, and it was learned that he was very avid for Moorish women and that it came from that." His shipmates declared that on leaving Algiers "this Moor had suffered discharges," although they had passed. The quarantine ended on 23 September without further incident. ${ }^{148}$

147 In 1727 four vessels from Mataró seized a launch that approached its coast with seven Muslims and a Genoese renegade on board; all were examined by medical officers and placed in quarantine: Iм Hв, FS, serie v, leg. 7, fols. 88-89, 11 October 1727. In Barcelona in 1729 the crew of a Tunisian galliot, twenty-one corsairs in all, were captured by the Malta squadron and likewise put in quarantine: Ім нв, FS, serie v, leg. 7, fols. 216-17, 20 June 1729 .

148 The pink had been sighted off Montjuich and captured by a squadron under the command of Álvaro Cabreros. Of the six drowned men one corpse floated to the surface, so the local health authorities forbade fishing for fifteen days in a radius of three leagues from the spot: Iмнв, Fs, Serie I, leg. 8, fols. 191-92, 195, 197-99, 210, 214-16, 218, 220-26, 22933: the reports are dated 2-4, 9-11, 14, 19, and 23 October 1754. Another doctor from the lazzaretto declared that the sick Algerian had "a swelling, as a result of some discharges he contracted in Puerto Mahón”: FS, Serie v, leg. 9, fols. 70-75, 12 and 18 September 1754. Serie I, leg. 8, fols. $238-4$ O. 
In $175^{6}$ a packet-boat belonging to Antonio Barceló seized a galliot and "after having killed twenty-six Moors aboard, brought the rest directly into this port." Five of the nineteen survivors - or thirteen, in another account - were injured ("he is bringing five seriously wounded and asks for a surgeon"). Their clothing was burned and, wearing new garments, they were taken to the lazzaretto in Barcelona, the healthy ones by land and the wounded in boats. One named Larrax, probably the captain, had three serious wounds: "one on his head almost to the bone, one hand almost severed, and his thigh pierced through and through." Moreover he presented "the novelty of a total blockage of urine from a stone in the neck of his urinary bladder, with a swelling or tumescence of the hypogastric region that I very much fear may produce an inflammation or kill him."149 That same month the king's xebecs arrived in Barcelona with an Algerian pink captured off Tossa with sixty-seven Moors aboard, three of them wounded; they were deposited in the lazzaretto to wait out their quarantine..$^{150}$

Another illuminating instance took place in 1757. In the waters off Palafrugell Captain Balanzó had "sent ... an Algerian frigate full of Moors to the bottom," after which his ship continued its journey. The town councillors reported that on 22 June they had ordered the Algerian survivors pulled from the water with fishing gear, so that twenty-seven were rescued. Some had taken refuge "on some rocks called the Formigas that are in the sea in sight of that town [Palamós] - sixteen Moors from a galliot that had fought with the pink of captain Juan Balansó of Mataró." Most of the captured men had severe wounds and were housed in a converted windmill and a tower near Palafrugell, under the authority of the town council. ${ }^{151}$ Ten crewmen aboard a Catalan boat that had been captured by an Algerian xebec, then retaken by two royal vessels, received similar treatment. ${ }^{152}$

149 This was one of the two Algerian galliots that had attacked Balanzó at the mouth of the River Llobregat: IM HB, Fs, Serie I, leg. 9, fols. 119, 121, 13 June 1756. The quarantine cost 2,213 reales de ardite and 12 sueldos: FS, I, leg. 10, fols. 8-9. Another doctor confirmed Larrax's diagnosis: "he cannot piss because of a stone that fills the opening to his bladder." Another quarantined man, Ali, was feverish: Fs, Serie I, leg. 11, fols. 79-82, 7 and 10 June 1762.

150 Імнв, FS, Serie I, leg. 11, fol. 93. Marqués de la Mina to board of health (Junta de Sanidad del Ayuntamiento), 19 June 1762.

151 The Board of Health of the royal Audiencia wanted to know if the Catalan captain had communicated with the corsairs, and requested information on the Catalan boat, its captain, and its destination. It received a report from the Commandant of Gerona and the town councillors of Palamós: IM HB, FS, serie V, leg. 9, fols. 178-79, 25 June 1757.

152 The ships, engaged in corsair warfare in the Mediterranean, were captained by Isidoro Postigo. The boat had been seized on 22 July 1757: Ім нB, FS, Serie v, leg. 9, fols. 221-22, 4 September 1757 . 
Sometimes an excess of zeal could result in tragedy. In August 1772 an Algerian galliot commanded by Captain Say was seized off Palamós; there had been thirty-eight Moors on board, of whom thirty-six survived to be brought into Barcelona. The Board of Health found fault with the medical treatment the slaves received, condemning in particular "the ill effects of the perfumes and baths given to the Moors and Turks brought in by the king's galliots." As a consequence of the fumigation they had undergone - using only one-sixth the amount of products that the law required, for the time it took to recite two Credos - the men emerged from quarantine "half dead, in convulsions, apoplectic, and with other effects." It was ordered that from then on there should be no more "fumigations nor baths for the syphilitic."153

At many other times during the 176 os there must have been incidents similar to the ones we have narrated, though our information about them is less clear.

Port authorities did not always allow captured Muslim corsairs to be quarantined in their lazzarettos; sometimes their entry was forbidden out of fear of plague. That was the case for twenty-nine Muslims captured in 1737 and taken to Málaga, ${ }^{154}$ and for the men of an Algerian xebec taken by the Galleys of Malta off Cadaqués in August 1758. ${ }^{155}$

Ransoms of Muslims are documented throughout the Early Modern age, though they were arranged more systematically by the late eighteenth century. Our information for the 1500 s is scarce and fragmentary. ${ }^{156}$ Some wellknown individuals were ransomed, like Ahmad b. al-Qadi, a captive in the south of Spain, who was redeemed by the Sultan of Morocco for the sum of twenty thousand escudos. ${ }^{157}$ In the Canary Islands ransoms were common in the sixteenth century and mostly designed to exchange captive Muslims for an

153 On their release from quarantine the Algerians were taken to the Ciutadella: Імнв, Fs, Serie I, leg. 13, fols. 92-93, 99-100: 29 August 1772 and 18 September 1772. Serie V, leg. 11, fols. 13-14: 4 December 1772.

154 The health authorities in Málaga, for fear of contagion, turned away Captain José Muñoz, commander of the frigate that had captured the ship, and all its crew: Імнв, Serie v, leg. 8, fol. 237, 28 September 1737 .

155 The Maltese galleys were ordered to take charge of the xebec and convey the captured Algerians out of the kingdom: IмнB, FS, Serie v, leg. 10, fols. 22-26, 2 September and 18 October 1758.

156 For ransoms of Muslims see Vidal Castro, "Le rachat des captifs musulmans."

157 Loukili, "D'une captivité musulmane à l'autre." The sultan pursued freedom for other subjects, including Captain Amar, enslaved in the Galleys of Spain. One of his ambassadors, Amete Voytade or Botarbo, obtained freedom for thirty-four Moroccans in Lisbon in 1582: Tarruell, "Circulations," 123. 
undetermined number of black Africans. ${ }^{158}$ In 1512 an ambassador from Tunis was authorized to ransom any Muslim slaves on Spanish territory that he could. ${ }^{159}$

From the late seventeenth to the end of the eighteenth century we have fuller and more precise information about ransoms, especially exchanges of captives. After the Moroccans took the fortress of Larache in 1689, the number of Spaniards enslaved provided motivation for both sides to exchange slaves and prisoners. The following year, when the Moroccan ambassador al-Gassani visited the court in Madrid, an exchange was agreed to by which an undetermined number of Muslim slaves, most of them Moroccan, were freed in response to the freeing of survivors of Larache. ${ }^{160}$ This trend grew stronger in the eighteenth century, as I will show in Chapter 5 .

In the period under study an unknown number of Muslim slaves gained their liberty through letters of manumission or a provision of their master's will. They were probably not many, since owners placed very heavy conditions on their slaves who wished to be freed. The so-called cortados, slaves hired out to third parties, found it especially difficult to pay the sums demanded. After the Moroccan ambassador Sidi Ahmed al-Gazzal had observed slaves in Cartagena, he remarked:

These slaves are very poor and needy, and what they gain after their hired labor is not enough to feed their children, because prices are so high. ... We spent a long time in their company while they wept and pleaded with us, and we cried and lamented even more. ${ }^{161}$

Even so, and bearing in mind that slaves who sought their freedom tended to exaggerate their misfortunes somewhat, their number was almost certainly larger than has generally been supposed. We shall return to this subject in Chapter 4.

\footnotetext{
$15^{8}$ Most Muslims captured by Canarians were exchanged for slaves from sub-Saharan Africa: Lobo Cabrera, "Rescates canarios."

159 Cortés Alonso, La esclavitud en Valencia, 419, 422.

16o Ben Hadda, $A$ Moroccan Ambassador; Arribas Palau, "De nuevo sobre la embajada de alGassani"; Vernet, "Embajada de al-Gassani"; Sauvaire, Voyage en Espagne d'un ambassadeur; Stanley, "Account of an Embassy from Morocco."

161 Paradela Alonso, El otro laberinto, 65.
} 
Attempts to flee were very frequent: there are documented cases in Cáceres, ${ }^{162}$ Badajoz, ${ }^{163}$ Jaén, ${ }^{164}$ Barcelona, ${ }^{165}$ and Cartagena, ${ }^{166}$ and they must have occurred also in many other cities and towns for which we still have no information. Since we hear only about those who were recaptured, there is no way to know how many escaped successfully.

We shall take up the question of religious practices among Muslim slaves in the section about free Muslims on Spanish soil.

The defeated and dispossessed Moriscos, like captured and enslaved Muslims (of whom many were caught while raiding Spanish shores in search of Christian slaves), formed a marginal population within Spain. Nor were they alone, for they shared that marginal status with paupers, convicts, and others whom society did not treat much better - including Gypsies, who like Muslims reacted with irreverence when religious processions passed by. Within that zone of exclusion Moriscos and Muslim slaves interacted with their counterparts, either sharing their misfortunes or competing with them for alms from respectable

162 Juan Ronquillo, "by nation a North African Moor," escaped from Cáceres in 1585 but was caught in Salamanca; the Morisco Alvar López, who also fled Cáceres, was arrested in 1582: Periáñez Gómez, Negros, 443, 449, 482.

163 Juan de Aliste, a Morisco slave from the village of Almendral in Badajoz, escaped to Mexico: Periáñez Gómez, Negros, 445.

164 Of eight escaped slaves at least four were Muslims whose names show they had been baptized: Francisco in 1676, Simón Alonso in 1677, Salvador in 1678, and Bernarda de Quiñones in 1689. All were recaptured: López Molina, Una década, 48-5o, 62, 70, 84.

165 On the night of 12 July 1762 two Algerians whose ship had been captured by Spanish vessels escaped their quarantine in the lazzaretto in Barcelona. One slipped his foot out of its manacle and the other took the manacle with him, breaking a link in its chain and carrying both manacle and chain away "in a manner that has amazed everyone because [the place] was well guarded at night." The town crier immediately proclaimed that anyone who helped the escapees would be sentenced to death. When they were recaptured in Malgrat on 30 July it was determined that they had had no accomplices: IM HB, FS, Serie V, leg. 10, fols. 102-03, 18 August 1762; Serie I, leg. 11, fols. 164, 168, 2 July and 12 July 1762.

166 On 12 April 1763 twenty Muslim slaves took over a fishing barge tied up in the shipyard and, having a favoring wind, managed to slip out of port even though they came under fire. A second barge manned by twelve soldiers and some officers and sailors, joined by two tenders manned by grenadiers and a Minorcan xebec, pursued them. The xebec caught up with the fugitives two leagues outside Pormán and engaged them in combat; the slaves defended themselves with rocks, but after six were killed and eight wounded they surrendered. A rumor in the city that all the Muslim slaves had revolted had the entire garrison mustered and armed, and in the confusion thirty-four Muslims were wounded before the true situation was known: Martínez Rizo, Fechas y fechos, 1:157. 
society. Often both Moriscos and cristianos nuevos de moro served as a bridge between Old Christians on the one hand and unrepentant Moriscos, together with free and enslaved Muslims, on the other.

Nonetheless a frontier did exist between the Moriscos and other marginalized groups, and between all of them and the larger society; neither side intermarried with the other, for example. ${ }^{167}$ Though the Moriscos had been baptized, most of them continued in their old faith, and virtually all of those expelled from Spain accepted their new reality and "returned" to the practice of Islam. Only a few embraced the Church sincerely.

As for Muslim slaves, most of those who became Christian had been baptized at birth, in numbers much larger than has been acknowledged until now. Both groups formed a sort of mirror image of the Christian renegades who became Muslim in lands of Islam.

Out of the hundreds of thousands of Muslim slaves only a small number gained their freedom, whether through manumission, an owner's testament, or self-purchase. Everything indicates that the great majority of these Muslim freedmen preferred to remain in Spain - both those who had converted to Christianity and those who had not.

${ }_{167}$ Amelang, Historias paralelas. 